a hawk from a handsaw, let alone from an eagle. Hamilton could, and his daring tropical trips gave him the raw material for many leaps of the scientific imagination. His last, published posthumously, argues that the plants with the brightest autumn colours are telling parasites that they are fit and healthy, and to go elsewhere. Hamilton, sad to say, was also a martyr to political vapourings and lobbied for a cracked eugenical Utopia with Margaret Thatcher as Life President and caesarian births banned.

A Reason for Everything is a well-written and carefully researched account of some of the main British players in the world of evolution. Every evolutionist should read it — as a warning against personality cults, if nothing else. Kohn makes it clear that giants walked the Earth in those days. Those days are gone, but after perusing his chapter on the Oxford school of evolutionary biology in the 1950s and 1960s - some geniuses, no doubt, but also a fair sprinkling of prima donnas and right-wing zealots - one can only mutter, through gently clenched teeth, "Thank God!"

Steve Jones is in the Galton Laboratory,

University College London, Gower Street,

London WC1E 6BT, UK.

\section{Well bred rodents}

\section{Making Mice: Standardizing Animals for American Biomedical Research, 1900-1955 \\ by Karen Rader \\ Princeton University Press: 2004. 312 pp. $\$ 45, £ 29.95$}

\section{Michael Festing}

Clarence Cook Little started his undergraduate work in genetics at Harvard's Bussey Institute in the class of 1910. This was soon after the field of genetics was established following the rediscovery of Gregor Mendel's classical paper on unit inheritance in peas. Initially Little studied the inheritance of coat colour in mice. In order to produce a pure line purged of recessive genes, and to study the effects of inbreeding, he mated brother and sister mice for several generations to produce DBA, the first inbred strain. He soon realized the importance of using pure-line mice in research, something that many research workers still do not appreciate today. Little's mice have made major contributions to our understanding of cancer and many other branches of mammalian biology. Without them we would probably not have monoclonal antibodies or a technique for knocking out individual genes in order to study their function.

In 1915, Little came to prominence in cancer research when he started a 30-year

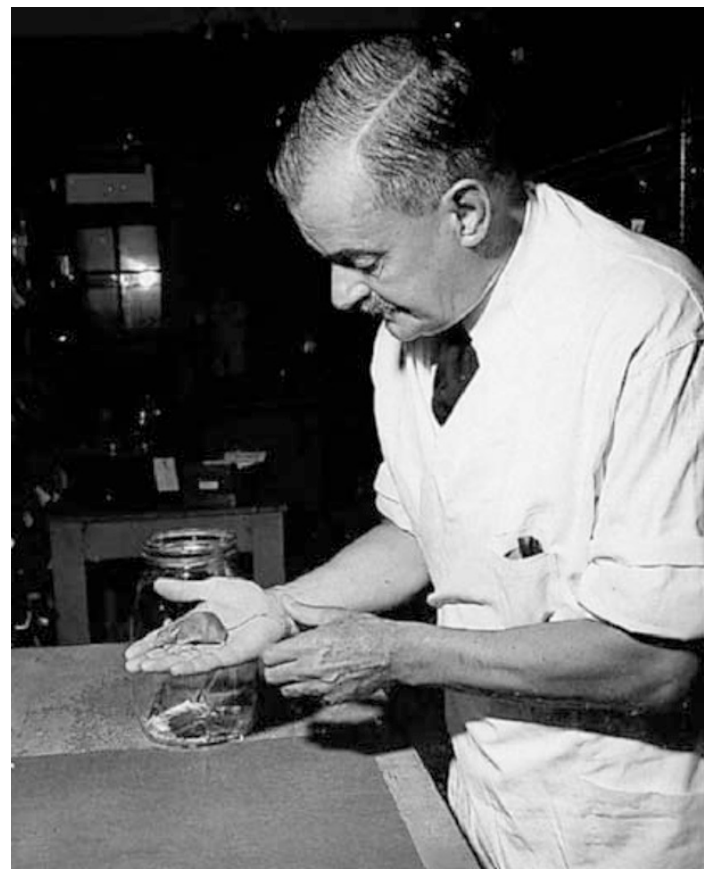

A helping hand: the pure-bred mice developed by Clarence Cook Little are a valuable tool for biomedical researchers.

scientific feud with Maud Slye, who claimed, based on studies with outbred mice, that cancer was inherited as a simple mendelian recessive character. Little was right: the cause of cancer is much more complicated, depending on many genes and environmental factors.

Little continued his research at the Cold Spring Harbor Laboratory, but in 1922, aged just 34, he was appointed president of the University of Maine. He subsequently met many of the rich summer visitors to Bar Harbor, including Roscoe B. Jackson, an engineer and joint founder of the Hudson Motor Car Company, who supported some of Little's research projects. With these connections and his strong research interests, Little obtained an even more prestigious appointment in 1925, as president of the University of Michigan.

Four years later, Little set up his own research institute in Bar Harbor on land donated by George Dorr. It was named, with Dorr's approval, the Roscoe B. Jackson Memorial Laboratory, after Jackson, who had died unexpectedly from influenza. Little could not have chosen a worse time. The stock-market crash of 1929 occurred within days and sources of support among the seasonal residents of Bar Harbor dried up. Little was forced to sell mice to keep the lab going, despite a tradition of supplying genetically interesting stock to colleagues free of charge. In subsequent years, many scientists and bureaucrats have found it difficult to understand how an organization could be both a research institute and a supplier of animals. Little emphasized repeatedly that the prime purpose of the laboratory was research, the supply of animals being a service to the research community.

In 1947 the Jackson Laboratory was destroyed in a fire that killed 14 people and thousands of mice. Little received many offers of help, and research scientists from throughout the United States sent back breeding pairs of mice to reestablish the colonies. By 1949 it had been rebuilt and continued in its role as a centre for mammalian genetics and biomedical research.

Making Mice is not exactly a history of inbred mice. There is no scientific account of the characteristics of such strains, nor of how they have made such a substantial contribution to biomedical research. Nor is it a biography of Little, who did so much to promote them; we learn only indirectly about the man and his background. I suspect that he was driven by his vision of pure-line mice as an essential research tool, and was intolerant of anyone who disagreed with him. Nor is it really a history of the Jackson Laboratory; there is, for example, a long section on the 'megamouse' experiments at Oak Ridge National Laboratory in Tennessee.

Rather, the book puts its three themes mice, Little and the Jackson Laboratory into historical context and weaves them together, the chapters following a rough chronology. It shows the tortuous path that finally led to the establishment of this world-renowned institute, and should be of interest both to historians and to scientists who work with genetically defined mice. There are a few misprints, however, and the book is incorrect in implying that rats, mice and birds are now protected under the US Animal Welfare Act.

The Jackson Laboratory has become an internationally recognized centre of excellence for research, teaching, informatics and the supply of genetically defined mice. The case for using inbred mice in research has largely been accepted, except in a few reactionary disciplines, such as toxicology. However, I consider it a major scientific scandal that in 2004, nearly a century after Little first advocated the widespread use of inbred, pure-line mice, more than $80 \%$ of scientific papers using the rat still involve genetically undefined Wistar or Sprague-Dawley rats. According to Little: "Just as the purity of the chemical assures the pharmacist of the proper filling of the doctor's prescription, so the purity of the mouse stock can assure a research scientist of a true and sure experiment." How many rats are being wasted as a result of the inability of many scientists to understand this simple point?

Michael Festing was formerly at the MRC

Toxicology Unit, Leicester LE1 9HN, UK. 